\title{
Biomolecular and micromorphological analysis of suspected faecal deposits at Neolithic Çatalhöyük, Turkey
}

Article

Accepted Version

Shillito, L.-M., Bull, I. D., Matthews, W., Almond, M., William, J. M. and Evershed, R. P. (2011) Biomolecular and micromorphological analysis of suspected faecal deposits at Neolithic Çatalhöyük, Turkey. Journal of Archaeological Science, 38 (8). pp. 1869-1877. ISSN 0305-4403 doi: https://doi.org/10.1016/j.jas.2011.03.031 Available at https://centaur.reading.ac.uk/21005/

It is advisable to refer to the publisher's version if you intend to cite from the work. See Guidance on citing.

Published version at: http://dx.doi.org/10.1016/j.jas.2011.03.031

To link to this article DOI: http://dx.doi.org/10.1016/j.jas.2011.03.031

Publisher: Elsevier

All outputs in CentAUR are protected by Intellectual Property Rights law, including copyright law. Copyright and IPR is retained by the creators or other copyright holders. Terms and conditions for use of this material are defined in the End User Agreement. 


\section{CentAUR}

Central Archive at the University of Reading

Reading's research outputs online 


\title{
Biomolecular and micromorphological analysis of suspected faecal deposits at Neolithic Çatalhöyük, Turkey
}

\author{
Lisa-Marie Shillito ${ }^{1}$, Ian Bull ${ }^{2}$, Wendy Matthews ${ }^{3}$. Matthew Almond ${ }^{4}$ \\ and Richard Evershed ${ }^{2}$ \\ ${ }^{1}$ BioArch, Department of Archaeology, University of York \\ ${ }^{2}$ Organic Geochemistry Unit, Bristol Biogeochemistry Research Centre, School of \\ Chemistry, Cantock's Close, Bristol, BS8 1TS, United Kingdom \\ ${ }^{3}$ Department of Archaeology, University of Reading \\ 4 Department of Chemistry, University of Reading
}

\begin{abstract}
Suspected coprolites from midden, burial and room fill contexts from Catalhoyuk were analysed by GC/MS and thin section micromorphology. Assessment of sterol biomarkers enabled a distinction between faecal and non-faecal sources for the deposits, with bile acid biomarkers indicating that many of the faecal deposits are human coprolites. The relative lack of ruminant faeces could be due to this material being used as a fuel source. Deposits in burials were observed to contain soil and plant derived sterols rather than their faecal counterparts. Further analysis in thin section enabled identification of associated materials and contents. Diagnostic inclusions such as bone and plant fragments were only present in some of the human coprolites, which were observed to have a very similar morphology to decayed plant remains. This study illustrates the difficulties in identifying coprolites in the field and under the microscope, and demonstrates the importance of integrating biogeochemical methods, particularly when such deposits are used as the basis for interpreting human health and diet, and use of space in settlements.
\end{abstract}

\section{Introduction}

Çatalhöyük is an early Neolithic site in south-central Anatolia, Turkey, dated between c.7400 - 6000 BC (Cessford et al. 2005). Discovered by James Mellaart in the late 1950s, the first excavations were carried out between 1961 and 1965 (Mellaart 1966) and it has become recognised internationally as the largest early settled village in the world, with remarkably well preserved wall paintings and sculptures (Hodder 2006). The abundant plant and faunal remains (Fairbairn et al. 2002, Russell and Martin 2005) mean it has become a key case study for understanding early settlement and agriculture in the Near East. In addition to extensive mudbrick architecture, a key feature of the site is the extensive midden deposits located adjacent to buildings, which are commonly reused as packing material (Shillito et al. 2008).

Faecal deposits are observed to be an abundant component of middens at many near eastern sites, through micromorphological observations of structure and inclusions such as bone fragments and hackberry pericarps (Matthews 2001, Matthews 2005, Shillito et al. 2009, Matthews 2010) and the presence of calcareous spherulites in herbivore dung 
(Canti 1999). The appearance of these deposits can be highly variable, some having a distinct sub-rounded morphology whilst others are present as amorphous organic stains or compressed layers interspersed between layers of ash and charred plants. These deposits have significant potential as indicators of human and animal diet and the large quantity of this material in close proximity to buildings at Çatalhöyük has significant implications for understanding health and use of space in the settlement. The accurate identification of faecal material as either human or animal is essential in the correct interpretation of archaeological deposits and to enable further investigation of health and diet in the Neolithic.

Identification of this material in the field is still uncertain, due to similarities in morphology and structure with deposits such as yellow ochre, clays and silts, and uncertainties about whether amorphous organic material may derive from decayed food remains (Matthews **). For example, mineralized phosphate-rich organic material inside hackberry pericarps has a similar appearance to omnivore coprolites in thin section (Shillito et al. 2009). Interpretation of yellow deposits in other contexts such as graves and room fill is also problematic, where it can be difficult to distinguish possible coprolites in the pelvic region of skeletons, and associated with faunal material, from non-faecal deposits.

In thin section, inclusions which distinguish faecal material from other organic deposits, such as spherulites and plant and bone fragments, may not always be present. In cases where plant and bone inclusions are visible, it may be difficult to distinguish between omnivore and ruminant derived deposits solely on the basis of external morphology and contents as human diet can be highly variable. Studies of Clovis period coprolites have debated whether the use of morphology and contents is a reliable species indicator (Goldberg et al. 2009, Rasmussen et al. 2009). Bimolecular analysis of organic residues by GC/MS can be used to identify coprolites with greater certainty, and is able to distinguish between omnivore and ruminant material on the basis of sterol content and between omnivore species on the basis of dominant bile acids (Elmmahli et al. 1997, Bull et al 2002).

The use of sterols and bile acids as biomarkers is possible due to the relative stability of these compounds combined with the specificity for different species. Soil and gut derived sterols can be distinguished on the basis of their stereochemistry, i.e. $5 \alpha$ products are the result of microbial breakdown in the soil rather than the $5 \beta$ - products

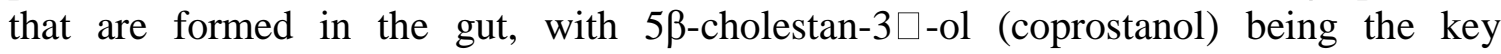
biomarker for human faeces, see Bull et al. $(1999,2002)$ for a detailed overview of the source and application of faecal biomarkers.

Pilot studies at Çatalhöyük have shown it is possible to recover significant quantities of sterols from samples of this age and to distinguish faecal material from mudbrick controls (Bull et al. 2005). On the basis of previous micromorphology studies and observations during excavations at Çatalhöyük (Matthews et al. 1996, Matthews 2005) it is hypothesised that distinct orange/yellow deposits in middens, room fill and graves are coprolites. It is further hypothesised that differences in coprolite micromorphology are 
due to the difference in species. The first hypothesis will be tested through biomolecular analysis of organic residues. The second hypothesis will be tested by comparing organic residue results with the appearance of the deposits in thin section.

Comparisons of the appearance of coprolites from finely stratified midden deposits in thin section will enable identification of the specific depositional context of these remains. This in turn can be used to help understand questions of midden formation processes, and provide the basis for further analysis of human and animal diet and health in the Neolithic. In addition, the comparison between microscopic and organic geochemical analyses will help future identifications of faecal material in thin section.

\section{Methods}

\section{Field sampling}

Middens were surveyed in each of the three major excavation areas at Çatalhöyük East (Figure 1(a)), and sections selected to investigate sequences of undisturbed, finely stratified layers, where yellow/orange inclusions, suspected to be faecal deposits, were visible at the macroscale. In addition, material collected as "coprolites" from burials and room fill deposits were selected. Samples for thin section micromorphology were collected by cutting blocks from midden faces and wrapping these with tissue and tape to avoid disturbing the deposits. Orange inclusions suspected to be faecal material were sub sampled directly from the face of the blocks, to allow direct comparison between biomolecular analysis and thin section micromorphology. In total 17 samples were selected from midden sections, 6 from room infill and 5 from burials. Samples and context details are given in Table 1. Excavation records with context data are available online at www.catalhoyuk.com.

\section{Biomolecular analysis}

Analyses were performed using GC and GC-MS. The extraction method is summarized

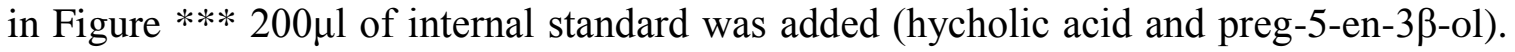
Organic residues were extracted for a minimum of 8 hours using a Soxhlet with $200 \mathrm{ml}$ dichloromethane (DCM): acetone 9:1 v/v. The total lipid extract (TLE) was saponified with $3 \mathrm{ml}$ of $5 \mathrm{M} \mathrm{KOH}$ in $90 \%$ methanol at $110{ }^{\circ} \mathrm{C}$ for $1 \mathrm{~h}$. The $\mathrm{pH}$ was then adjusted to 34 using $6 \mathrm{M} \mathrm{HCl} .3 \mathrm{ml}$ of diethyl ether was added and the sample was mixed thoroughly. Residual water was removed by passing the organic layer through anhydrous $\mathrm{Na}_{2} \mathrm{SO}_{4}$. Acid and neutral fractions were separated using Phenomenex strata $\mathrm{NH}_{2}$ aminoproyl bonded-phase SPE cartridges.

The first eluate collected with the DCM/isopropanol 2:1 v/v is the neutral fraction containing $n$-alkyl alcohols and sterols, with the more polar acid fraction remaining on the column. The acid fraction was eluted separately using $6 \mathrm{ml} \mathrm{MeOH}+5 \%$ acetic acid. The neutral fraction was further split into mixed neutrals and the important alcohol fraction using a silica gel 60 column. Samples were transferred to the column with $1 \mathrm{ml}$ DCM, and eluted with 2ml DCM: MeOH. 
The solvent from the polar fraction (including bile acids) was removed under nitrogen and redissolved in $1 \mathrm{ml}$ methanol and methylated with $10 \mathrm{ml}$ diazomethane in diethylether at room temperature overnight. The diethylether and excess diazomethane were removed under nitrogen and the residue was dissolved in DCM/hexane and further fractionated on activated silica gel. The samples were eluted with a further $5 \mathrm{ml}$ aliquot of DCM/hexane then with DCM/methanol. Acids and sterols were converted to trimethylsilyl (TMS) derivatives by adding $100 \mu \mathrm{TMS}$ reagent and then leaving to stand under nitrogen at 70 ${ }^{\circ} \mathrm{C}$ for $1 \mathrm{~h}$. The fully extracted samples were then diluted and the hexane phase was analysed

In order to identify the likely source of any biomarkers present, three ratios can be calculated:

Ratio 1: Coprostanol/(coprostanol $+5 \alpha$-cholestanol)

Ratio 2: Coprostanol + epicoprostanol / (coprostanol + epicoprostanol $+5 \alpha$-cholestanol)

Ratio 3: (Coprostanol+epicoprostanol)/(5 $\beta$-stigmastanol+5 $\beta$-epistigmastanol)

It has been proposed that for Ratio 1, a value greater than 0.7 is a definite indicator of faecal pollution (Grimalt et al. 1990). Ratio 2 has been proposed by Bull et al. (2002) to account for diagenetic processes leading to the formation of epicoprostanol. Archaeological values are thus adjusted to take into account the further transformation of coprostanol compared to $5 \alpha$-cholestanol. Ratio 3 is used to confirm if the presence of faecal material is from either pig/human, or a ruminant species.

\section{GC and GC/MS conditions}

The samples were injected into a GC and separated with a silica capillary column. The oven was held for $1 \mathrm{~min}$ at $40{ }^{\circ} \mathrm{C}$, then the temperature was increased from 40 to $230{ }^{\circ} \mathrm{C}$ at $20^{\circ} \mathrm{C} \mathrm{min}^{-1}$. The temperature was then increased to $300{ }^{\circ} \mathrm{C}$ at $2{ }^{\circ} \mathrm{C} \mathrm{min}{ }^{-1}$ for 20 minutes. He was used as a carrier gas, with a flame ionisation detector to monitor eluent. GC-MS peak assignments were made by comparison with known mass spectra.

\section{Thin section preparation and analysis}

Resin impregnation was carried out using Taab epoxy resin under vacuum, hardened at $70^{\circ} \mathrm{C}$ for $12 \mathrm{~h}$. Slides were prepared by successively cutting and grinding the block face to a standard thickness of 30 microns. Micromorphological descriptions were carried out according to standard terminology and by comparisons with previously published and reference material (Matthews et al. 1996, Matthews 2005, Bullock et al. 1985, Courty et al. 1989) 


\section{Results}

Biomolecular analysis of organic residues by $G C-M S$

The abundance of sterols, relative to each other, is shown in Table 2. The origin of the residues is given first by the ratios discussed earlier (Bull et al. 2002), and through examining bile acids present. The initial study at Çatalhöyük showed a human origin for four of the seven deposits studied (Bull et al. 2005) with the values of Ratio 3 obtained from the coprolite samples being 0.79 and 0.92 , and the midden deposit samples having values of 0.83 and 1.00. These values are well above the threshold value of 0.7 .

In the present study, values returned using Ratio 1 are consistent with sixteen of the 28 deposits being of faecal origin with a further four possibly comprising faeces mixed with another deposit type. Of these twenty, values returned using Ratio 3 suggest that seventeen are derived from omnivores (values ranging from 0.75 to 1.88 ), one is possibly of ruminant origin (value of $* *$ ), and two may be ruminant/omnivore mixed. Further clarification through analysis of bile acids supports a human origin for the omnivore coprolites due to the presence of both lithocholic and deoxycholic acid.

For the 11 non-faecal samples, 3 contain no residues, with 5 having a non-faecal source, indicated by the dominance of cholesterol, sitosterol and $5 \alpha$-stigmastanol rather than the $5 \beta$-stanols formed in the gut. This pattern is observed in three of the burial samples and two of the midden samples and can be interpreted as the remains of decayed plant material. Thin section observation of the two midden samples with non-faecal residues indicates that these are anthropogenic clay fragments and the plant residues are likely to be from the decayed plant material used as temper. This can be seen in thin section by the presence of abundant pseudomorphic voids, which remain as impressions in the clay after the organic temper has decayed.

Sterols observed in $1380 \mathrm{~S}$ ? taken from a grave context in the North Area indicate that it is not of faecal origin, and the concentrations of sitosterol and $5 \alpha$-stigmastanol in this sample are relatively high, at 2.0 and $7.5 \mu \mathrm{g} \mathrm{g}^{-1}$ respectively. It is suggested that these are the result of decayed plant remains.

Burial sample $1985 \mathrm{~S} 5$ has a noticeably high concentration of cholesterol at $2.58 \mu \mathrm{g} \mathrm{g}^{-1}$ compared to $0.02 \mu \mathrm{g} \mathrm{g}^{-1}$ coprostanol, with other residues of $5 \alpha$-cholestanol $\left(0.06 \mu \mathrm{g} \mathrm{g}^{-1}\right)$, $5 \alpha$-campestanol $\left(0.32 \mu \mathrm{g} \mathrm{g}^{-1}\right)$, sitosterol $\left(0.97 \mu \mathrm{g} \mathrm{g}^{-1}\right)$ and $5 \alpha$-stigmastanol $\left(2.76 \mu \mathrm{g} \mathrm{g}^{-1}\right)$. The presence of cholesterol has been noted in studies of mummies, but the cholesterol has not been attributed to any specific source (Buckley and Evershed 2001, Buckely et al 2004). Cholesterol has also been observed in studies of mummies by Degano and Columbini (2009), where it is interpreted as deriving from human skin. However in this study it is likely to be plant derived, considering the high quantities of other plant derived sterols.

Midden sample 13103 S24 contains cholesterol and sitosterol only, excluding a faecal origin, whilst 12504 S16 contains small quantities of cholesterol, 5 $\beta$-stigmastanol, 
sitosterol and $5 \alpha$-stigmastanol. Although this contains a $5 \beta$-stanol, the low concentration at $0.01 \mu \mathrm{g} \mathrm{g}^{-1}$ and the lack of any other $5 \beta$-stanols, suggests that it does not have a faecal source and can be considered as a minor background quantity of $5 \beta$-stigmastanol.

Samples that did not contain faecal sterols were also lacking in LC or DOC, confirming that these do not contain faeces, whilst the samples with omnivore faecal sterol ratios all contain LC and DOC. This confirms the presence of human faecal material in these samples. Sample 1 (4477 S7), observed to contain a mix of ruminant and omnivore faeces was seen to contain DOC only, whilst 11016 S4 observed to contain possible ruminant faecal material, did not contain detectable traces of bile acids. The lack of any hyodeoxycholic acid excludes a porcine origin for the omnivore coprolites.

\section{Thin section micromorphology}

Selected deposits analysed for faecal residues were observed in thin section for comparison of the specific context, associations and micromorphological features. Micromorphological features are summarized in Table 3. The size and morphology of the deposits range from distinct sub rounded inclusions embedded in an ashy matrix, to amorphous material with a less distinct morphology. A more linear morphology is observed in some deposits due to compression, perhaps from trampling.

The colour of the deposits ranges is variable and ranges from a pale yellowish brown to a very intense orange. All of the deposits have an amorphous fine fabric, with some containing phosphate nodules, plant voids and embedded bone fragments and phytoliths. None of the samples observed has the linear fibrous structure and high level of plant inclusions associated with animal dung. No faecal spherulites were observed.

Deposits with a distinct morphology are very well preserved with minimal postdepositional alterations. Deposits with a more amorphous structure appear to be partially disaggregated, likely to be a result of bioturbation - occurring predominantly in samples from the later Neolithic deposits in the TP area.

A number of samples recorded as coprolites in the field do not appear to be organic remains in thin section, supported by the lack of faecal residues. These include clay deposits with mineral inclusions and pseudomorphic voids from decayed plant temper, which demonstrate that these are anthropogenic aggregates such as ceramic production debris (Matthews et al. 1997).

\section{Discussion}

Analysis of the results has distinguished deposits as omnivore faeces, deposits containing non-faecal residues, or deposits that do not contain any residues. Samples with corresponding thin sections have enabled comparison between GC/MS results and micromorphology. Results are discussed for each of the three context types investigated, 
followed by the implications of this for wider questions at Çatalhöyük and the Near Eastern Neolithic, and other sites containing such deposits.

\section{Middens}

Sediment samples from middens have been shown previously to contain high levels of faecal residues (Bull et al. 2005). This study has integrated thin section micromorphology to the study of a wider range of deposits, and indicates that faecal residues are present in coprolite deposits present as distinct inclusions in middens, which can be observed in situ in thin section. In the present study, samples from middens were most frequently identified as human faeces on the basis of sterol and bile acid distributions, compared to burial and room fill contexts which were more variable.

However, not all midden deposits analysed were confirmed as human coprolites. The ratio of $\mathrm{C} 27$ to $\mathrm{C} 29$ 5b-stanols (Ratio 3) in one deposit (11016 S4) returned a value of 0.048 suggesting the presence of ruminant derived faecal material, but further examination of this data indicate only $0.002 \mu \mathrm{g} \mathrm{g}^{-1}$ of coprostanol are present, and no bile acids. Additional comparisons were made with the corresponding thin section and block photographs. The deposit is observed to consist of amorphous orange organic material associated with clay, and does not have the linear fibrous structure associated with ruminant dung (Courty et al. 1989, Akeret and Rentzel 2001). However there are no inclusions in the organic deposit that would enable this to be interpreted as faeces without ambiguity. The bright orange amorphous structure appears almost identical to other deposits identified as human faeces, such as 12519 S9, and demonstrates the difficulty in distinguishing between faecal and non-faecal organic material in thin section.

Three deposits in middens (7867/02, 13103 S24 and 12504 S16) did not contain faecal sterols or bile acids. These are most likely anthropogenic aggregates on the basis of further macroscale and thin section observations. 7867/02 is a silty aggregate which is harder and courser than the coprolites. 13103s34 contains a course aggregate with pseudomorphic voids indicating plant temper, and was embedded in a large ash layer, containing reed phytoliths and dung spherulites. This is a baked clay fragment and the sterols present are likely to be due to decayed plant material used as temper. 8864 is described as a coprolite in the Çatalhöyük database record but does not contain any residues, either faecal or plant derived. Unit data indicate the presence of numerous mudbrick fragments in this unit, which could suggest this sample is also mudbrick incorrectly identified as a coprolite. These examples illustrate the difficulties in distinguishing these deposits in the field.

\section{Burials}

The burial contexts are particularly interesting. Four of the samples analysed from burials were found to contain no faecal residues, with only one sample hypothesized to be a coprolite from a burial being found to contain faecal residues in this study, and these were found in very low concentrations compared to other contexts. A lack of faecal 
residues in the burials could be due to poor preservation, although this seems unlikely considering the high recovery of faecal residues from other contexts. The lack of faecal residues in the burial deposits therefore refutes the hypothesis that these are faecal deposits, as suggested when the samples were collected in the field.

However, three of the five burial samples did contain plant sterols including sitosterol

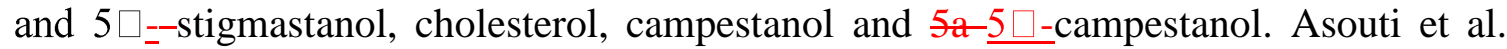
(1999) suggest the importance of plants in burials, but also note the lack of charred macrobotanical remains in these contexts which have previously made this hypothesis difficult to support. Considering the burial context these three samples could be interpreted as decayed plant material deposited in the grave, supporting early suggestions of the deliberate inclusion of plants in graves (Mellaart 1967) as well as more recent phytolith and botanical studies which have found impressions of reed baskets and caches of hackberry pericarps, for example in the burial beneath Building 6 in the $\mathrm{BACH}$ area (Asouti et al. 1999). These results suggest that whilst some of the material identified as coprolites in burials in the field has been accurately identified, it is likely that some of these yellow deposits are related to the death and decay of plants placed in the burials. Further interpretation of this material in burials therefore requires biomolecular analysis for correct identification as either coprolite or decayed plant remains.

\section{Room fill}

Five of the six room fill samples contained faecal residues, with the $6^{\text {th }}$ sample containing plant sterols only. These deposits are from Building 2, Space 117, excavated in 1997 (samples 2754 S2 and S4, 2766 S5 and 2767 S4). Archive excavation data for this unit debates whether these are yellow ochre or coprolites, with a tentative interpretation being that these represent animal penning during an intermediate phase between house floors and demolition back fill (Reagan, in Farid 1997). Reagan also notes the presence of large animal bones scattered either over or within the deposit. Faunal records indicate the presence of digested bone and mention the possibility of dog faeces based on these inclusions.

However, micromorphological analysis suggests that these were omnivore rather than ruminant coprolites and were unlikely to be penning areas due to the lack of sediment compaction (Matthews 2005). Biomolecular analysis of these samples presented here indicates the faeces present is human not animal, confirmed by both sterol and bile acid residues and supports Matthews' hypothesis that this was a latrine area rather briefly used as a waste dumping or toilet area in an abandoned building, before being back filled with building demolition debris. The building debris layers reported by Reagan (in Farid 1997) that overly the coprolitic layer are interspersed with finer deposits of "midden like" ashy and bone material, which would also suggest some cyclical use of this area as midden.

Implications for the Identification of coprolitic deposits in the field 
The presence of faecal residues, non-faecal residues and a lack of any residues in some deposits can now be used to discuss the implications for identifying coprolites in the field, particularly samples collected from burials, and as non-discreet orange deposits (or "stains") in the field. The recovery of relatively high concentrations of residues from samples observed to be discrete orange deposits in the field and in thin section suggests identification of coprolites from such discrete concretions is more reliable. Some samples identified as coprolites in the field are shown to be mudbrick and clay fragments on the basis of micromorphology and residue analysis. Other coprolites suggested to be dog on the basis of their context and associations in the field, are shown to be human. This illustrates the difficulty in identification of coprolites purely on the basis of visible morphological characteristics, and highlights the importance of biomolecular analysis for correct interpretation.

\section{Identification of coprolitic material from middens in thin section}

Analyses of samples from the TP Area (8932 S3, S5, S9 and S13) indicate that these are all human faecal material, confirmed by the presence of faecal sterols and bile acids. Observation of these deposits in thin section shows them to be amorphous organic material with few inclusions that would enable them to be confidently interpreted as coprolites. This illustrates the benefit of organic residue analysis in interpreting the fine organic layers observed in many thin section samples. This also indicates that assignment of amorphous organic material in thin section without a clear structure could be the remains of decayed plant remains rather than faecal material. Caution needs to be taken therefore in assigning organic remains as faecal material, particularly when this assignment is fundamental to the interpretation.

Of four samples from unit 13103 in the 4040 area, three were identified as human faeces on the basis of sterols ** (13103 S34, S21, S27). These are seen in thin section to be amorphous organic material, again with few inclusions. Sample 13103 S24 did not contain faecal residues - micromorphology demonstrates that this is a clay fragment containing plant material as temper. Although distinguishing between different omnivore species in thin section is difficult, this study confirms that other micromorphological features, such as a lack of trampling, are good indicators to distinguish animal penning areas.

Deposits such as clay and ochre fragments, which may not be clear in the field, are easily distinguishable from faecal material in thin section. Distinguishing between omnivore species is more difficult. There is no clear difference between human faecal material with an orange or yellow-brown colour. Both types are shown to be human on the basis of residues and the reasons for their different appearance is unclear but could be related to preservation or diet.

Implications of faecal residues for the interpretation of midden formation processes and human activity, and diet 
Analysis of midden formation processes, and subsequently human activities, relies on the characterisation of finely stratified deposits, including ash, partially charred plant material, bone fragments and organic remains. The distinction between human and animal waste, and between coprolites and other inclusions, is essential in interpreting activities. In turn the correct identification of coprolites as either human or animal enables the inclusions within the coprolites to be analysed in dietary studies.

The dominance of human faecal material is surprising considering the large amount of animals present at the site, indicated through analysis of faunal remains (Russell and Martin 2005) and identification of animal pens and faecal spherulites in hearths and middens (Matthews et al. 1996, Matthews 2005). This could suggest that animal faeces were not being deposited in the middens, perhaps because they were used as fuel, evidence of which is presented in this study through the presence of calcareous spherulites in ash deposits. A dominance of human faecal residues have been observed in other prehistoric contexts such as the Neolithic/Bronze Age site of Sanday, Orkney, where they are suggested to have been applied to soils as manure. In this study there was also an absence of cattle or sheep manure, with the suggestion being that these were used preferentially as a fuel source (Simpson et al. 1998). However it must also be noted that this could be due to a sampling bias, as ruminant faeces may be more difficult to identify in the field.

One midden deposit, 2739, contains human faecal residues, also contains hackberry inclusions. As these are a seasonally available food resource, this deposit provides a seasonal marker for examining midden formation processes.

\section{Species}

No samples show an unambiguous ruminant origin. 4477 is shown to possibly contain faeces from a ruminant species, with the value calculated for Ratio 1 suggesting a mixture of faecal material with another deposit and Ratio 3 suggesting a mix of omnivore and ruminant faeces (coprostanol and cholesterol are found in similar, low quantities at 0.024 and $0.026 \mu \mathrm{g} \mathrm{g}^{-1}$ respectively). Bile acid results for this sample reveal the presence of DOC. However concentrations of residues in this sample are too low to confirm whether it is of ruminant origin without ambiguity.

\section{Conclusions}

Biomolecular analysis of organic residues in orange/yellow deposits from midden, room fill and burial contexts at Çatalhöyük has demonstrated the presence of faecal sterols in some, but not all of the deposits. In deposits identified as faeces, these are interpreted as human on the basis of sterol distributions and bile acids present.

Comparison of organic residue results with the appearance of the deposits in thin section has demonstrated that some organic remains which do not contain diagnostic inclusions, such as bone and plant fragments, are in fact coprolites. However, some organic remains without diagnostic inclusions do not contain faecal residues. It is also noted that some 
deposits contain only plant derived sterols. Comparison of the appearance of these in thin section shows the presence of pseudomorphic voids from decayed plant temper, and it is suggested that the plant sterols are a result of this plant material. Plant derived sterols are also present in some of the burial samples, refuting the hypothesis that these deposits are coprolites in the pelvic region of skeletons.

The identification of human faecal deposits in close proximity to buildings is interesting from a health and use of space perspective. The relative lack of herbivore faecal deposits could be a result of this material being burnt as fuel. The presence of yellow organic deposits in graves, identified as the remains of decayed plants, provides direct evidence for the inclusion of plants as grave goods.

The comparison between microscopic and organic geochemical analyses presented here has implications for future identifications of faecal material in thin section. This demonstrates that interpretation of decayed organic remains in thin section can be ambiguous, and that biomolecular analysis is necessary for the correct interpretation of such remains.

\section{References}

Akeret, O. and Rentzel, P. (2001) Micromorphology and Plant Macrofossil Analysis of Cattle Dung from the Neolithic Lake Shore Settlement of Arbon Bleiche 3

Geoarchaeology: An International Journal Vol. 16, No. 6, 687-700

Asouti, E., Erkal, A., Fairbairn, A., Hadtorf, C., Kennedy, A., Near, J. and Rosen, A. M. (1999) Archaeobotany and Related Plant Studies. Çatalhöyük Archive Report.

Bull, I. D., Elhmmali, M. M., Perret, P., Matthews, W., Roberts, D. J. and Evershed, R. P. (2006) Biomarker evidence of faecal deposition in archaeological sediments at Çatalhöyük, Turkey. Inhabiting Çatalhöyük: Reports from the 1995-1999 seasons. I. Hodder (ed) London, McDonald Institute for Archaeology/British Institute of Archaeology at Ankara.

Bull, I.D., Lockheart, M.J., Elhmmali, M.M., Roberts, D.J. and Evershed R.P. (2002) The origin of faeces by means of biomarker detection. Environment International 27(8): 647-654.

Bull, I. D., Simpson, I. A., van Bergen, P. F. and Evershed, R. P. (1999) Muck 'n' molecules: Organic geochemical methods for detecting ancient manuring. Antiquity 73 , 86-96.

Bullock, P, Federoff N., Jongerius, A., Stoops, G. and Tursina, T. (eds). (1985). Handbook for thin section description. WAINE Research Publications. Albrighton, Wolverhampton, U.K.

Canti, M. G. (1999) The Production and Preservation af faecal Spherulites: Animals, Environment and Taphonomy. Journal of Archaeological Science 26: 251-258. 
Cessford, C., Blumbach, M., Akoglu, G., Higham, T., Kunihom, P. I., Manning, S. W., Newton, M. W., Ozbakan, M. and Ozer, A. M. (2005). Absolute Dating at Çatalhöyük. Changing Materialities at Çatalhöyük: Reports from the 1995 - 1999 Seasons. I. Hodder (ed) Cambridge, McDonald Institute for Archaeological Research and the British Institute of Archaeology at Ankara.

Courty, M. A., Goldberg, P. and Macphail, R. (1989) Soils and Micromorphology in Archaeology. Cambridge, Cambridge University Press.

Ehlmalli et al.

Ilaria Degano, Maria Perla Colombini, Multi-analytical techniques for the study of preColumbian mummies and related funerary materials, Journal of Archaeological Science, Volume 36, Issue 8, August 2009, Pages 1783-1790, ISSN 0305-4403, DOI:

10.1016/j.jas.2009.04.015.

Elhmmali, M., Roberts, D. J. and Evershed, R. P. (1997) Bile acids as a new class of sewage pollution indicator. Environmental Science and Technology 31: 3663-3668.

Fairbairn, A., Asouti, E., Near, J. and Martinoli, D. (2002) Macro-botanical evidence for plant use at Neolithic Çatalhöyük south-central Anatolia, Turkey. Vegetation History and Archaeobotany 11: 41-54.

Farid, S. (1997) Mellaart Area Çatalhöyük Archive Report

Goldberg, P., Berna, F. and Macphail, R (2009) Comment on "DNA from Pre-Clovis Human Coprolites in Oregon, North America" Science 325, 148-c.

Grimalt, J. O., Fernandez, P., Bayona, J. M. and Albaiges, J. (1990) Assessment of faecal sterols and ketone as indicators of urban sewage inputs to coastal waters. Environmental Science and Technology 24: 357 - 63.

Hodder, I. (2006) The Leopard's Tale: Revealing the Mysteries of Çatalhöyük. Thames and Hudson.

Matthews, W (2010) Quaternary International

Matthews, W. (2005a) Micromorphological and microstratigraphic traces of uses and concepts of space. Inhabiting Çatalhöyük: Reports from the 1995-1999 seasons. I. Hodder (ed) London, McDonald Institute for Archaeology/British Institute of Archaeology at Ankara. 355-399.

Matthews, W. (2001) in Matthews, R. and Postage, N. (ed) Contextual analysis of the use of space at two Near Eastern Bronze Age sites. http://ads.ahds.ac.uk/catalogue/projArch/TellBrak/ 
W. Matthews; C. A. I. French; T. Lawrence; D. F. Cutler; M. K. Jones (1997)

Microstratigraphic traces of site formation processes and human activities World Archaeology 29: 281 - 308

Matthews, W., French, C., Lawrence, T. and Cutler, D. (1996) Multiple surfaces: the micromorphology. In: Hodder, I. 1996. On the Surface Çatalhöyük 1993-95. McDonald Institute for Archaeological Research / British Institute of Archaeology at Ankara Monograph. 301-42

Mellaart, J. (1967) Çatal Huyük: A Neolithic Town in Anatolia. McGraw-Hill.

Rasmussen, M. Linda Scott Cummings, M. Thomas P. Gilbert, Vaughn Bryant, Colin Smith, Dennis L. Jenkins, and Eske Willerslev. (2009) Response to comment by Goldberg et al. on "DNA from Pre-Clovis human coprolites in Oregon, North America". Science 326, 148. DOI: 10.1126/science.1167672

Russell, N. and Martin, L. (2005). Çatalhöyük Mammal Remains. Inhabiting Çatalhöyük: reports from the 1995-99 seasons. I. Hodder (ed) Cambridge, Macdonal Institute / British Institute of Archaeology at Ankara.

Simpson, I. A., Dockrill, S. J., Bull, I. D. and Evershed, R. P. (1998) Early anthropogenic soil formation at Tofts Ness, Sanday, Orkey. Journal of Archaeological Science 25: 729-746. 
Table 2 - Percentage of identified sterol components, ratios of faecal sterols, and presence of bile acids for the deposits analysed. Values of Ratio $1>* *$ indicate faeces, values of Ratio 1 around 0.5 indicate faeces mixed with another deposit. Values of Ratio $3>* *$ indicate omnivore faeces, the presence of LC and DOC indicates human faeces dp. Yes comment agreed - you need to include something like "The sterols are numbered as follows....then give a list in order....Ratio $1=$, Ratio $3=-$ and define the ratios)

\begin{tabular}{|c|c|c|c|c|c|c|c|c|c|c|c|c|c|c|c|c|c|}
\hline $\begin{array}{l}\text { Midde } \\
\mathrm{n} \\
\text { sample } \\
\mathrm{s}\end{array}$ & & 1 & 2 & 3 & 4 & 5 & 6 & 7 & 8 & 9 & 10 & 11 & 12 & $\begin{array}{l}\text { Ratio } \\
1\end{array}$ & Ratio 3 & DOC & $\mathbf{L C}$ \\
\hline 8864 & 4 & - & - & - & - & - & - & - & - & - & - & - & - & - & - & - & - \\
\hline 11016 & 4 & 0.21 & & 19.56 & - & - & - & - & 4.49 & - & - & 26.56 & 49.17 & 1.00 & 0.05 & - & - \\
\hline 13103 & 34 & 21.06 & 1.44 & 12.08 & 0.78 & - & - & - & 19.79 & - & 10.42 & 19.40 & 15.02 & 0.96 & 0.75 & $\sqrt{ }$ & $\sqrt{ }$ \\
\hline 13103 & 24 & - & - & 60.87 & - & - & - & - & 0.00 & - & - & 39.13 & 0.00 & - & - & - & - \\
\hline 13103 & 21 & 19.78 & 1.93 & 10.13 & 3.59 & 4.35 & 3.08 & - & 21.56 & - & 4.98 & 15.57 & 15.03 & 0.85 & 0.82 & $\sqrt{ }$ & $\sqrt{ }$ \\
\hline 13103 & 27 & 34.44 & 5.68 & 12.46 & 2.12 & 4.44 & 1.17 & - & 24.81 & - & 3.78 & 6.13 & 4.98 & 0.94 & 1.4 & $\sqrt{ }$ & $\sqrt{ }$ \\
\hline 1668 & $\mathrm{U} 1$ & 8.98 & - & 6.08 & 3.18 & - & - & - & 8.20 & 2.40 & - & 21.41 & 49.75 & 0.74 & 1.09 & $\sqrt{ }$ & $\sqrt{ }$ \\
\hline 2739 & $8 b$ & 23.34 & - & 3.40 & 4.71 & - & - & - & 28.67 & 1.70 & - & 13.44 & 24.74 & 0.83 & 0.81 & $\sqrt{ }$ & $\sqrt{ }$ \\
\hline 12519 & 7 & 34.09 & 6.07 & 10.30 & 2.11 & 2.92 & - & - & 18.92 & - & 4.27 & 12.08 & 9.24 & 0.94 & 1.73 & $\sqrt{ }$ & $\sqrt{ }$ \\
\hline 12519 & 8 & 17.29 & 3.07 & 15.36 & 0.90 & - & - & - & 22.41 & - & 1.92 & 26.76 & 12.29 & 0.95 & 0.84 & $\sqrt{ }$ & $\sqrt{ }$ \\
\hline 12524 & 14 & 8.11 & - & 30.86 & 7.52 & - & - & - & 9.50 & - & - & 28.59 & 15.43 & 0.52 & 0.85 & - & - \\
\hline 12504 & 15 & 12.70 & 0.54 & 10.86 & 1.74 & - & - & - & 18.68 & - & 2.71 & 39.96 & 12.81 & 0.88 & 0.62 & $\sqrt{ }$ & $\sqrt{ }$ \\
\hline 12504 & 16 & - & - & 25.30 & - & - & - & - & 7.01 & - & - & 51.22 & 16.46 & - & - & - & - \\
\hline 7867 & 02 & - & - & - & - & - & - & - & - & - & - & - & - & - & - & - & - \\
\hline 8932 & $3 / 13$ & 5.96 & - & 8.74 & 5.10 & - & - & - & 5.25 & - & - & 23.24 & 51.71 & 0.54 & 1.12 & $\sqrt{ }$ & $\sqrt{ }$ \\
\hline 8932 & $3 / 05$ & 28.34 & - & 11.32 & 8.88 & - & - & - & 15.04 & 3.84 & - & 10.08 & 22.50 & 0.76 & 1.88 & - & - \\
\hline 8932 & $3 / 09$ & 22.43 & - & 14.36 & 5.08 & 1.36 & - & - & 16.82 & 3.73 & - & 13.05 & 23.17 & 0.82 & 1.33 & $\sqrt{ }$ & $\sqrt{ }$ \\
\hline $\begin{array}{l}\text { Burial } \\
\text { sample } \\
\text { S }\end{array}$ & & 1 & 2 & 3 & 4 & 5 & 6 & 7 & 8 & 9 & 10 & 11 & 12 & $\begin{array}{l}\text { Ratio } \\
\mathbf{1}\end{array}$ & Ratio 3 & DOC & $\mathbf{L C}$ \\
\hline
\end{tabular}




\begin{tabular}{|c|c|c|c|c|c|c|c|c|c|c|c|c|c|c|c|c|c|}
\hline 1380 & 1 & - & - & - & - & - & - & - & - & - & - & 49.90 & 50.10 & - & - & - & - \\
\hline 1494 & 6 & 4.90 & - & 11.14 & 1.84 & - & - & - & 5.40 & 7.20 & - & 16.87 & 52.65 & 0.73 & 0.91 & $\sqrt{ }$ & - \\
\hline 1993 & 4 & - & - & - & - & - & - & - & - & - & - & - & - & - & - & - & - \\
\hline 1380 & $?$ & - & - & 4.62 & - & - & - & $\begin{array}{l}0.2 \\
1\end{array}$ & - & 0.67 & - & 20.06 & 74.45 & - & - & - & - \\
\hline 1985 & 5 & 0.27 & - & 37.57 & 0.94 & - & - & $\begin{array}{l}2.1 \\
4\end{array}$ & - & 4.67 & - & 14.10 & 40.31 & 0.23 & - & $\sqrt{ }$ & $\sqrt{ }$ \\
\hline $\begin{array}{l}\text { Room } \\
\text { infill/ } \\
\text { midde } \\
\mathrm{n} \\
\text { sample } \\
\mathrm{s} \\
\end{array}$ & & 1 & 2 & 3 & 4 & 5 & 6 & 7 & 8 & 9 & 10 & 11 & 12 & $\begin{array}{l}\text { Ratio } \\
\mathbf{1}\end{array}$ & Ratio 3 & DOC & LC \\
\hline 4477 & 7 & 5.46 & - & 8.42 & 3.98 & - & - & - & 9.53 & 4.78 & - & 22.85 & 44.98 & 0.58 & 0.57 & $\sqrt{ }$ & - \\
\hline 2754 & 2 & 18.95 & - & 16.47 & 1.64 & 1.91 & - & - & 19.59 & 0.97 & - & 17.63 & 22.84 & 0.93 & 0.96 & - & $\sqrt{ }$ \\
\hline 2766 & 5 & 10.82 & - & 6.07 & 0.06 & - & - & - & 6.45 & 0.08 & - & 36.68 & 39.84 & 0.99 & 1.68 & $\sqrt{ }$ & $\sqrt{ }$ \\
\hline 2754 & 4 & 27.43 & - & 7.28 & 2.08 & 6.71 & - & - & 28.52 & 5.00 & - & 6.61 & 16.38 & 0.93 & 0.96 & $\sqrt{ }$ & $\sqrt{ }$ \\
\hline 2767 & 4 & 19.64 & - & 8.80 & 4.33 & 0.89 & - & - & 15.39 & 1.47 & - & 16.51 & 32.98 & 0.82 & 1.28 & $\sqrt{ }$ & $\sqrt{ }$ \\
\hline 1360 & 1 & - & - & - & - & - & - & - & - & & - & 49.90 & 50.10 & & - & $\sqrt{ }$ & $\sqrt{ }$ \\
\hline
\end{tabular}

1. coprostanol 2. epicoprostanol 3. cholesterol 4. 5 $\square_{-}$-cholestanol 5. $5 \square_{-}$-campestanol 6. $5 \square_{--}$-epicampestanol 7. campestanol 8. $5 \square$ stigmastanol 9.5 $\square$--campestanol 10.5 $\square$ _-epistigmastanol 11. sitosterol 12. $5 \square$ _-stigmastanol. 
Table 1 - Samples for organic residue analysis by GC/MS. Context data for archive samples from Çatalhöyük database.

\begin{tabular}{|c|c|c|c|c|c|}
\hline \multicolumn{6}{|c|}{ Middens } \\
\hline Area & Context & $\begin{array}{l}\text { Sample } \\
\text { number }\end{array}$ & $\begin{array}{l}\text { Level } \\
\text { Mellaart/ } \\
\text { Hodder }\end{array}$ & Context description & $\begin{array}{l}\text { Thin } \\
\text { section }\end{array}$ \\
\hline 4040 & 8864 & 4 & $\mathrm{~V}, \mathrm{III}$ & $\begin{array}{l}25 \mathrm{~cm} \text { thick, multiple fine } \\
\text { layers with mudbrick. } \\
\begin{array}{l}\text { Sample collected as } \\
\text { coprolite. }\end{array}\end{array}$ & - \\
\hline 4040 & 13103 & 34 & & $\begin{array}{l}\text { Orange material adjacent to } \\
\text { massive aggregate deposits. }\end{array}$ & $\begin{array}{l}13103 \\
\text { S20 }\end{array}$ \\
\hline 4040 & 13103 & 24 & & $\begin{array}{l}\text { Orange deposit in large ash } \\
\text { layer with plant inclusions. }\end{array}$ & $\begin{array}{l}13103 \\
\text { S25 }\end{array}$ \\
\hline 4040 & 13103 & 21 & & $\begin{array}{l}\text { Thin orange lense } \\
\text { associated with fine ashy } \\
\text { layers. }\end{array}$ & $\begin{array}{l}13103 \\
\text { S22 }\end{array}$ \\
\hline 4040 & 13103 & 27 & & $\begin{array}{l}\text { Thin orange } \\
\text { associated with multiple } \\
\text { fine layers and brown } \\
\text { organics. }\end{array}$ & $\begin{array}{l}13103 \\
\text { S26 }\end{array}$ \\
\hline 4040 & 13103 & 23 & & $\begin{array}{l}\text { Orange aggregate in ash } \\
\text { layer }\end{array}$ & $\begin{array}{l}13103 \\
\text { S25 }\end{array}$ \\
\hline & 13013 & 3 & & & \\
\hline South & 1668 & U1 & & Space 115 , coprolite. & - \\
\hline South & 2739 & $8 \mathrm{~b}$ & & $\begin{array}{l}\text { Space } 115.3 \text { to } 4 \text { layers of } \\
\text { ashy deposits, with } \\
\text { interleaved lenses of } \\
\text { coprolite and phytoliths. }\end{array}$ & - \\
\hline South & 12519 & 7 & & $\begin{array}{l}\text { Thin orange } \\
\text { associated with } \\
\text { fine layers. }\end{array}$ & $\begin{array}{l}12519 \\
\text { S9 }\end{array}$ \\
\hline South & 12519 & 8 & & $\begin{array}{l}\text { Thin orange } \\
\text { associated with multiple } \\
\text { fine layers. }\end{array}$ & $\begin{array}{l}12519 \\
\text { S9 }\end{array}$ \\
\hline South & 12524 & 14 & & Orange deposit & \\
\hline South & 12524 & 13 & & Orange deposit under ash & \\
\hline South & 12504 & 15 & & $\begin{array}{l}\text { Thin orange lense } \\
\text { associated with multiple } \\
\text { fine layers. }\end{array}$ & $\begin{array}{l}12504 \\
\text { S17 }\end{array}$ \\
\hline South & 12504 & 16 & & $\begin{array}{l}\text { Thin orange } \\
\text { associated with } \\
\text { fine layers. }\end{array}$ & $\begin{array}{l}12504 \\
\text { S17 }\end{array}$ \\
\hline South & 12558 & 1 & & $\begin{array}{l}\text { Orange aggregate in ash } \\
\text { layer? }\end{array}$ & $\begin{array}{l}12558 \\
\text { S2 }\end{array}$ \\
\hline
\end{tabular}




\begin{tabular}{|c|c|c|c|c|c|}
\hline South & 12558 & 4 & & $\begin{array}{l}\text { Orange lense interspersed } \\
\text { with ashy deposits }\end{array}$ & $\begin{array}{l}12558 \\
\text { S3 }\end{array}$ \\
\hline $\mathrm{TP}$ & 7867 & 02 & & Orangey-brown deposit & 7867 \\
\hline & & & & $\begin{array}{l}\text { associated with grey ashy } \\
\text { layers. }\end{array}$ & S3 \\
\hline $\mathrm{TP}$ & 8932 & $3 / 13$ & & $\begin{array}{l}\text { Yellow deposit associated } \\
\text { with ashy grey lenses }\end{array}$ & $\begin{array}{l}8932 \\
\text { S3 }\end{array}$ \\
\hline $\mathrm{TP}$ & 8932 & $3 / 05$ & & $\begin{array}{l}\text { Yellow deposit associated } \\
\text { with ashy grey lenses }\end{array}$ & $\begin{array}{l}8932 \\
\text { S3 }\end{array}$ \\
\hline $\mathrm{TP}$ & 8932 & $3 / 09$ & & $\begin{array}{l}\text { Yellow deposit associated } \\
\text { with ashy grey lenses }\end{array}$ & $\begin{array}{l}8932 \\
\text { S3 }\end{array}$ \\
\hline \multicolumn{6}{|c|}{ Burials } \\
\hline Area & Context & $\begin{array}{l}\text { Sample } \\
\text { number }\end{array}$ & $\begin{array}{l}\text { Level } \\
\text { Mellaart/ } \\
\text { Hodder }\end{array}$ & Context description & $\begin{array}{l}\text { Thin } \\
\text { section }\end{array}$ \\
\hline North & 1380 & 1 & & $\begin{array}{l}\text { Building 1, Space 110, } \\
\text { Feature } 28 . \quad \text { Between } \\
\text { mandible and sternum. }\end{array}$ & - \\
\hline North & 1380 & $?$ & & $\begin{array}{l}\text { Building 1, Feature 28, } \\
\text { Space } 100\end{array}$ & - \\
\hline North & 1494 & 6 & & $\begin{array}{l}\text { Building 1, Space 71, } \\
\text { Feature } 40 .\end{array}$ & - \\
\hline North & 1993 & 4 & & $\begin{array}{l}\text { Building 1, Space 71, } \\
\text { Feature 29/49, ?ochre }\end{array}$ & - \\
\hline North & 1985 & 5 & & $\begin{array}{l}\text { Building 1, Space } 71, \\
\text { Feature 211. Adult and } \\
\text { child burial. }\end{array}$ & - \\
\hline \multicolumn{6}{|c|}{ Room fill/midden } \\
\hline Area & Context & $\begin{array}{l}\text { Sample } \\
\text { number }\end{array}$ & Level & Context description & $\begin{array}{l}\text { Thin } \\
\text { section }\end{array}$ \\
\hline South & 4477 & 7 & & $\begin{array}{l}\text { Building 23, } \\
\text { 178/179. Mixed with } \\
\text { orangey and greyish brown } \\
\text { clayey silts, with plaster } \\
\text { and brick debris. }\end{array}$ & - \\
\hline South & 2754 & 2 & & $\begin{array}{l}\text { Building 2, Space 117, } \\
\text { overlying plaster floor. }\end{array}$ & - \\
\hline South & 2754 & 4 & & $\begin{array}{l}\text { Building 2, Space 117, } \\
\text { overlying plaster floor. }\end{array}$ & - \\
\hline South & 2766 & 5 & & $\begin{array}{l}\text { Building 2, Space 117, } \\
\text { overlying plaster floor. }\end{array}$ & - \\
\hline South & 2767 & 4 & & $\begin{array}{l}\text { Building 2, Space 117, } \\
\text { overlying plaster floor. }\end{array}$ & - \\
\hline North & 1360 & 1 & VII, VI & Building 1, Space 71. & - \\
\hline
\end{tabular}




$\begin{array}{lllll}4040 & 11016 & 4 & \begin{array}{l}\text { Orangey-brown deposit } 11016 \\ \text { under room fill }\end{array}\end{array}$

Table 3- Micromorphological observations of orange deposits observed in thin section

\begin{tabular}{|c|c|c|c|c|}
\hline Area & Sample & Colour & Structure and inclusions & Post-depositional \\
\hline \multirow[t]{2}{*}{$\mathrm{TP}$} & $8932 / 05$ & $\begin{array}{l}\text { Yellow- } \\
\text { brown }\end{array}$ & $\begin{array}{l}\text { Disaggregated/amorphous with } \\
\text { bone fragments }\end{array}$ & \\
\hline & $8932 / 09$ & $\begin{array}{l}\text { Yellow- } \\
\text { brown }\end{array}$ & Disaggregated/amorphous & \\
\hline \multirow[t]{5}{*}{4040} & $\begin{array}{l}13103 \mathrm{~s} 2 \\
7\end{array}$ & $\begin{array}{l}\text { Pale } \\
\text { orange }\end{array}$ & Fibrous, abundant linear voids & \\
\hline & $\begin{array}{l}13103 \mathrm{~s} 2 \\
4\end{array}$ & $\begin{array}{l}\text { Reddish } \\
\text { brown }\end{array}$ & $\begin{array}{l}\text { Abundant pseudormorphic } \\
\text { voids }\end{array}$ & \\
\hline & $\begin{array}{l}13103 \\
\mathrm{~s} 21\end{array}$ & & & \\
\hline & 11016 & orange & Amorphous & Microbial staining \\
\hline & $7867 / 02$ & $\begin{array}{l}\text { Pale } \\
\text { orange- } \\
\text { brown }\end{array}$ & & \\
\hline \multicolumn{5}{|l|}{4040} \\
\hline \multirow[t]{4}{*}{ South } & $12519 \mathrm{~s} 7$ & Orange & Dense, few voids & \\
\hline & $12558 \mathrm{~s} 3$ & $\begin{array}{l}\text { Yellow- } \\
\text { brown }\end{array}$ & $\begin{array}{l}\text { Abundant digested bone } \\
\text { fragments }\end{array}$ & \\
\hline & $12558 \mathrm{~s} 2$ & Orange & $\begin{array}{l}\text { Bone fragment with sharp } \\
\text { edges }\end{array}$ & \\
\hline & 3922.10 & Yellow & Plant voids, phytoliths & \\
\hline
\end{tabular}



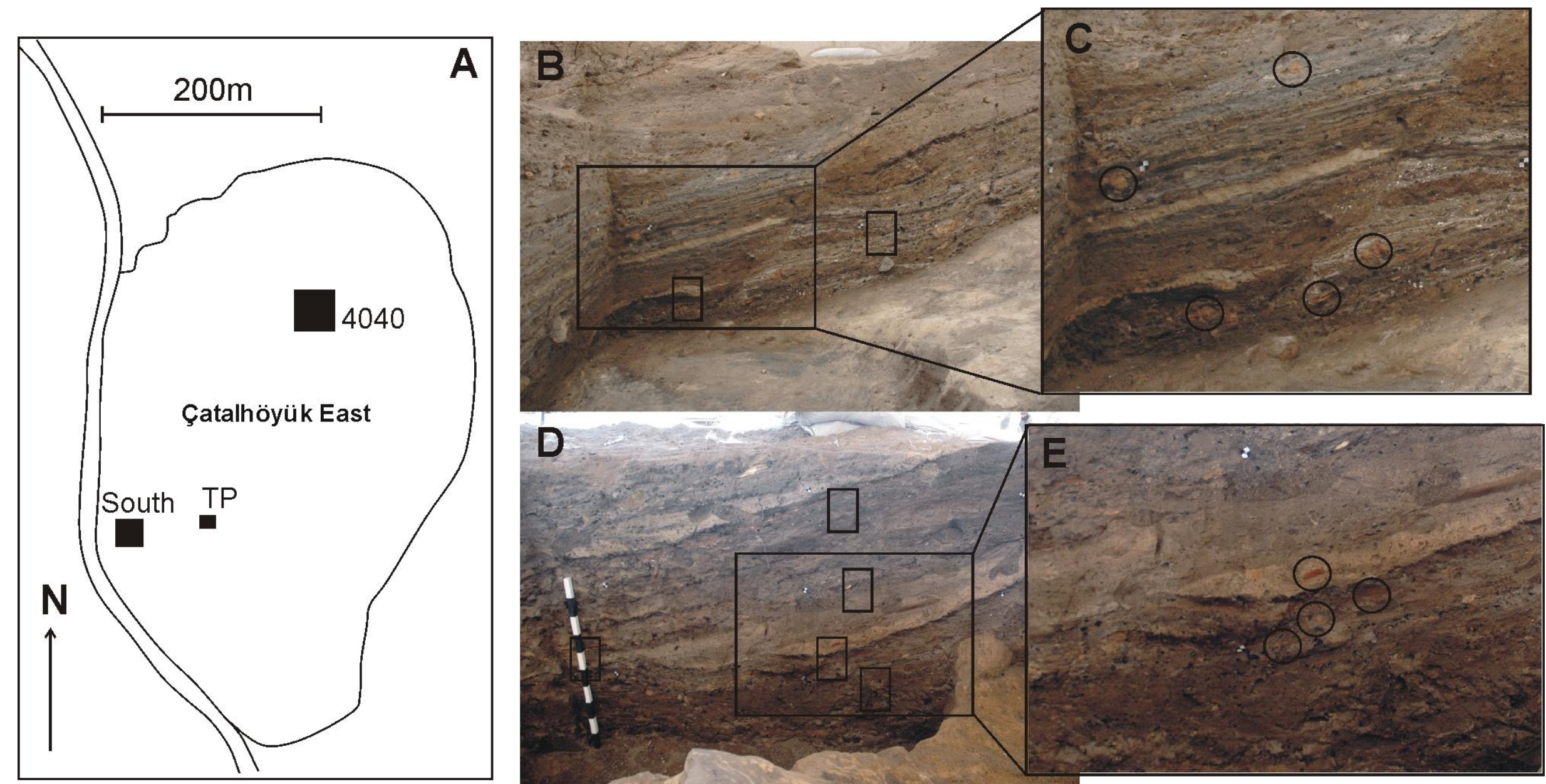

Figure 1 A Plan of Çatalhöyük showing the excavation areas investigated in this study, B South Area midden with C. examples of suspected coprolites in the field. D. 4040 Area midden with E. examples of suspected coprolites. 


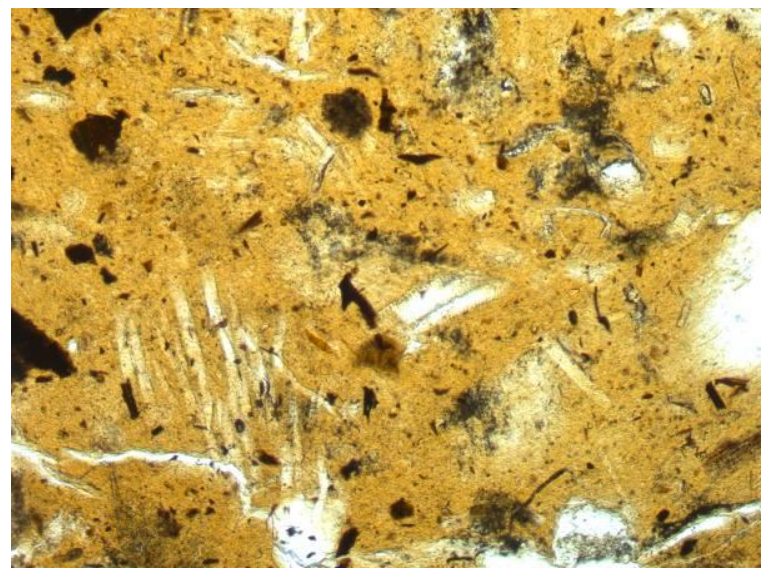

$3922.10 \mathrm{~A}$

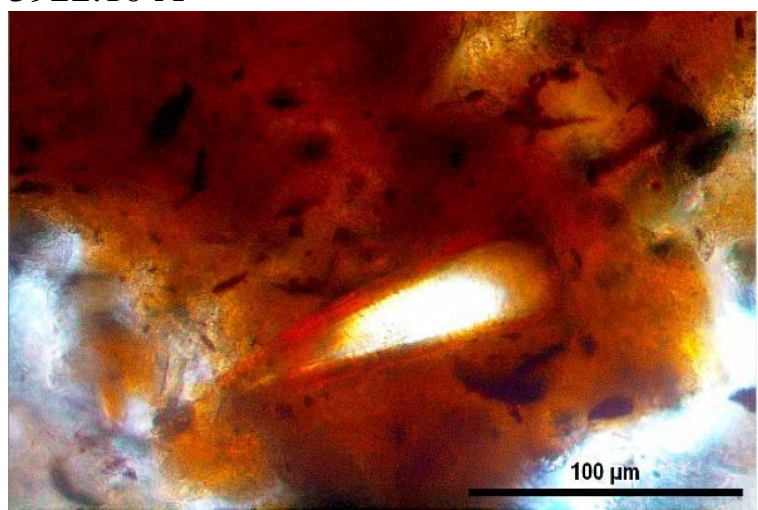

12558 s2 C

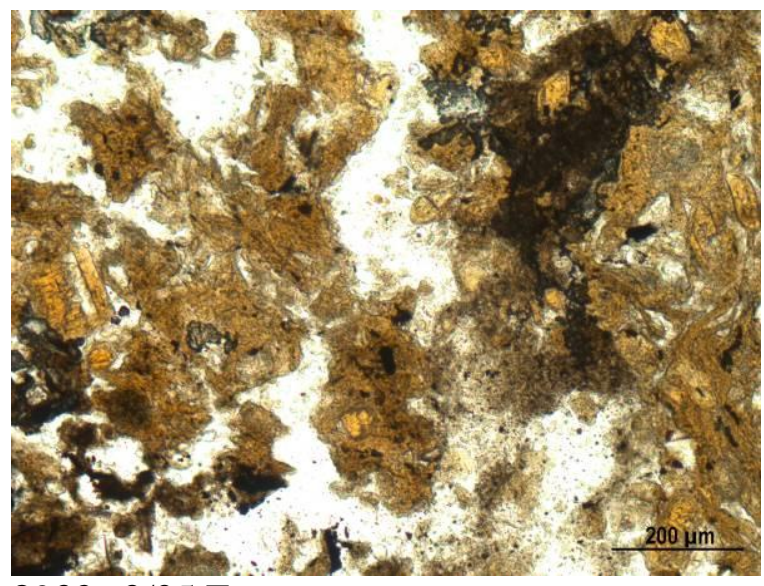
8932 s3/05 E
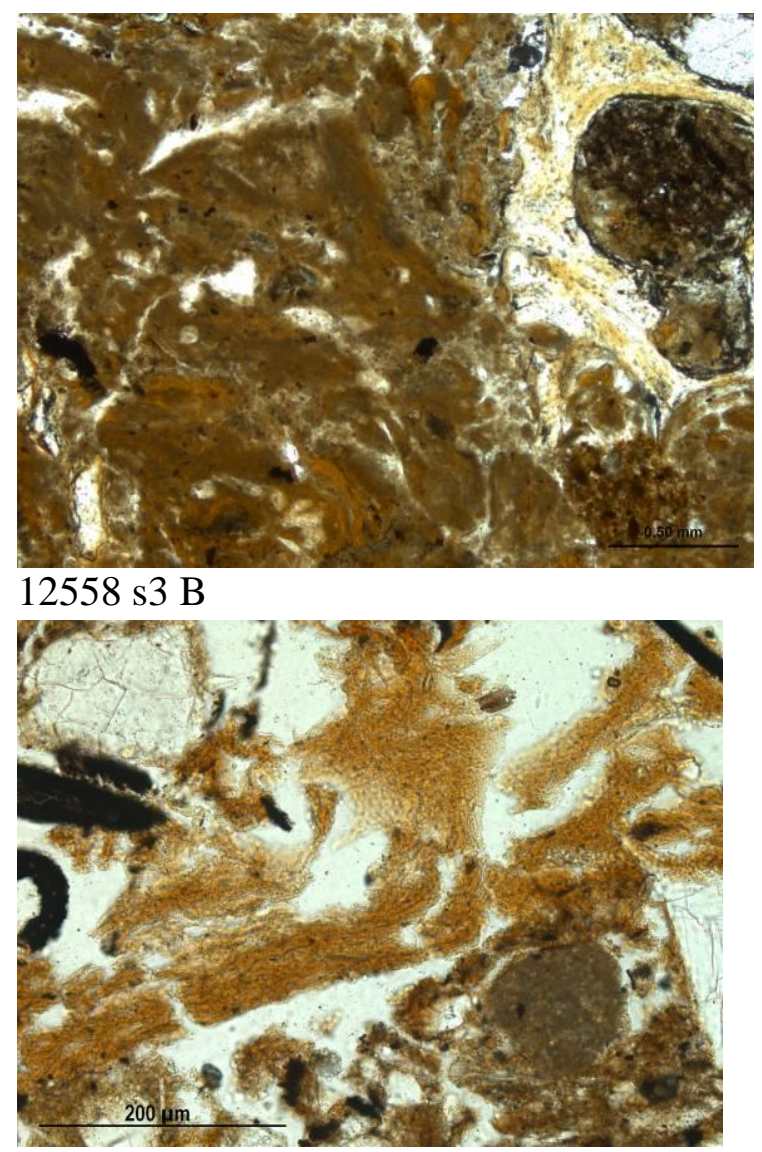

13103 s26 D

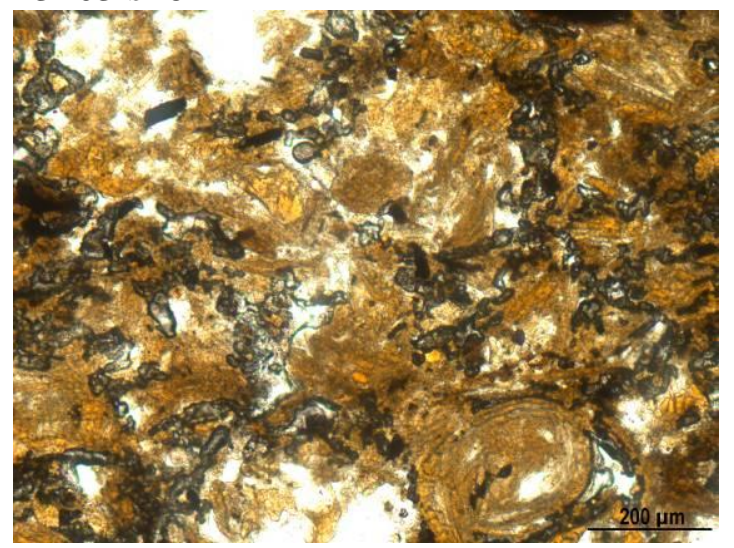

8932 s3/09 F 


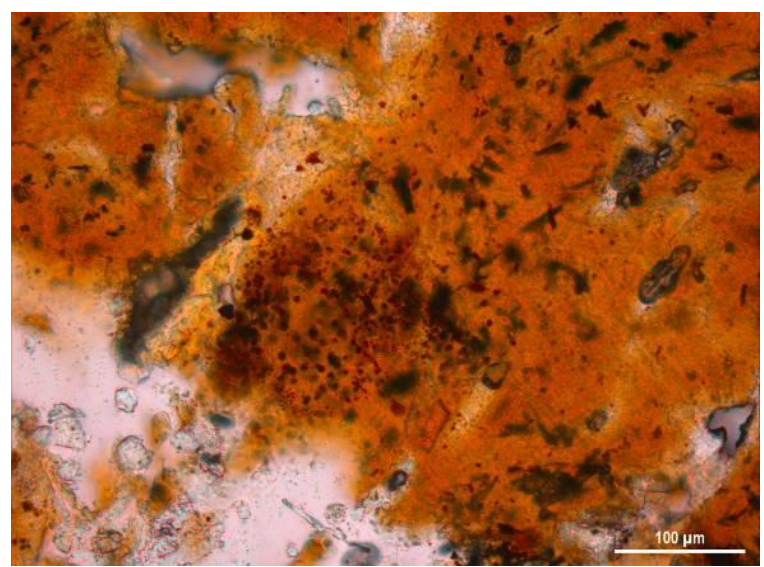

11016 s2 G

Suspected faecal deposits in thin section. 